\title{
PENERAPAN MODEL STAD UNTUK MENINGKATKAN HASIL BELAJAR IPA SISWA KELAS IV
}

\author{
Ni Komang Junmalini \\ Jurusan Pendidikan Guru Sekolah Dasar, Fakultas IImu Pendidikan \\ Universitas Pendidikan Ganesha \\ Singaraja, Indonesia \\ e.mail : Junmalini26@g.mail.com
}

\begin{abstract}
Abstrak
Tujuan penelitian ini adalah untuk mengetahui peningkatkan hasil belajar IPA siswa Kelas IV SD No. 2 Sembung Tahun Pelajaran 2016/2017 setelah penerapan model pembelajaran kooperatif tipe Student Teams Achievement Division (STAD). Penelitian ini menggunakan rancangan penelitian tindakan kelas yang dilakukan dalam dua siklus. Subjek penelitian adalah siswa kelas IV SD No. 2 Sembung yang berjumlah 21 orang. Data penelitian tentang hasil belajar dikumpulkan dengan menggunakan metode tes. Data yang telah terkumpul dianalisis secara deskriptif kuantitatif. Hasil analisis data menunjukkan ratarata persentase skor hasil belajar IPA pada siklus I sebesar $68,09 \%$ berada pada kategori sedang dan mengalami peningkatan sebesar $12,48 \%$ pada siklus II menjadi $90,47 \%$ tergolong pada kategori sangat tinggi. Maka penerapan model pembelajaran kooperatif Tipe Student Teams-Achievement Division (STAD) dapat meningkatkan hasil belajar IPA siswa kelas IV SD No 2 Sembung.
\end{abstract}

Kata kunci: model pembelajaran, kooperatif tipe STAD, hasil belajar

\begin{abstract}
The purpose of this study was to determine the improvement of student learning outcomes. Class IV IPA SD No. 2 Sembung in the academic year 2016/2017 after the implementation of cooperative learning model Student Teams Achievement Division (STAD). This study uses the design of classroom action research conducted in two cycles. Subjects were students in fourth grade No. 2 Sembung totaling 21 people. The research data on learning outcomes was collected using test method. The collected data were analyzed by descriptive quantitative. The results of data analysis showed that the average percentage score of science learning outcomes in the first cycle of $68.09 \%$ in the medium category and an increase of $12.48 \%$ in the second cycle into $90.47 \%$ belong to the very high category. The implementation of cooperative learning model type Student Teams-Achievement Division (STAD) can improve learning outcomes class IV IPA SD No. 2 Sembung.
\end{abstract}

Key words: learning model, cooperative STAD, learning outcomes.

\section{PENDAHULUAN}

Di era globalisasi ilmu pengetahuan dan teknologi selalu berkembang, untuk itu pendidikan akan selalu mengantisipasi dan membicarakan pembangunan tersebut untuk masa depan. Pendidikan hendaknya melihat jauh ke depan dan memikirkan tentang apa yang akan dihadapi siswa di masa yang akan datang. Hal tersebut berdampak pada pendidikan harus dilaksanakan dengan sebaik-baiknya untuk memperoleh hasil maksimal. Sesuai dengan amanat Undang-Undang Republik Indonesia Nomor 20 Tahun 2003 tentang Sistem Pendidikan Nasional pada Bab II Pasal 3 yang berbunyi, Pendidikan nasional berfungsi mengembangkan kemampuan dan membentuk watak serta peradaban bangsa yang bermartabat dalam rangka mencerdaskan kehidupan bangsa, bertujuan untuk berkembangnya potensi peserta didik agar menjadi 
manusia yang beriman dan bertakwa kepada Tuhan Yang Maha Esa, berakhlak mulia, sehat, berilmu, cakap, kreatif, mandiri, dan menjadi warga negara yang demokratis serta bertanggung jawab.

Salah satu upaya untuk meningkatkan mutu pendidikan adalah melalui perbaikan proses pembelajaran pada setiap mata pelajaran yang dilaksanakan di kelas. Salah satu usaha yang dilakukan untuk mencapai pembelajaran yang optimal adalah dengan menggunakan model dan media yang tepat sesuai dengan kemampuan siswa serta sesuai dengan materi pelajaran yang akan dijelaskan oleh guru di kelas (Dimyati \& Mudjono, 1994; Hariyanto, 2011; Trianto, 2012).

Mata pelajaran IPA merupakan bidang studi yang menduduki peranan penting dalam dunia pendidikan, karena "IPA adalah pengetahuan rasional dan objektif tentang alam semesta dengan segala isinya" (Darmojo, 1993). Pembelajaran IPA sebaiknya dilaksanakan secara kooperatif untuk menumbuhkan kemampuan berpikir, bekerja dan bersikap ilmiah serta mengkomunikasikannya sebagai aspek penting kecakapan hidup. Oleh karena itu pembelajaran IPA di SD menekankan pada pemberian pengalaman belajar secara langsung melalui penggunaan model dan media yang tepat, serta mengembangkan keterampilan proses dan sikap ilmiah.

Dalam kaitannya untuk meningkatkan proses pembelajaran khususnya pembelajaran IPA di sekolah dasar, maka sikap, fungsi dan peran guru haruslah mengalami pergeseran yaitu: (1) konservatif-tradisional menuju progresiffuturistik; (2) penceramah-menggurui menuju pendengar yang empati, fasilitator dan mediator pembelajaran; dan (3) sumber otoritas pengetahuan menuju manager informasi.

Dengan demikian para guru khususnya guru mata pelajaran IPA di sekolah dasar sudah saatnya berbenah diri dari model pembelajaran konvensional beralih ke model pembelajaran yang berdasarkan atas paradigma kontruktivis. Paham kontruktivis sangat memandang perlu pergeseran paradigma pembelajaran yang berpusat pada guru (teachercentered) menjadi pembelajaran yang berpusat pada siswa (student-centered). Pada pandangan kontruktivis belajar pada hakikatnya merupakan suatu proses modifikasi gagasan yang sudah ada dalam pikiran pebelajar, dimana belajar merupakan proses modifikasi gagasangagasan yang telah ada dalam pebelajar. Belajar merupakan pembentukan pengertian atas pengalaman-pengalaman dalam hubunganya dengan pengetahuan yang telah dimiliki sebelumnya (Rusman, 2011).

Pada proses kegiatan pembelajaran IPA di SD No 2 Sembung, suasana pembelajaran masih kurang kondusif. Hal ini terlihat pada kegiatan diskusi kelompok hanya didominasi oleh siswa yang pandai, sementara siswa yang kemampuannya rendah kurang berperan dalam mengerjakan tugas kelompok. Dalam diskusi kelompok terlihat tidak ada kerjasama atau saling membantu antara anggota kelompok. Selain itu siswa kurang aktif dalam proses pembelajaran di kelas, baik dalam hal mengajukan pertanyaan, menjawab pertanyaan yang disampaikan oleh guru ataupun merespon dan menanggapi jawaban dari temannya. Dalam pembelajaran hanya didominasi oleh guru, partisipasi dan keaktifan siswa belum muncul. Hal ini dapat menyebabkan aktivitas belajar siswa rendah.

Hasil belajar IPA siswa kelas IV di SD No 2 Sembung, masih tergolong rendah. Hal ini terlihat dari rata-rata hasil belajar ulangan harian siswa baru mencapai 60,89 (dikutip dari daftar nilai siswa kelas IV Tahun Pelajaran 2016/2017). Kriteria Ketuntasan Minimal (KKM) hasil belajar yang harus dicapai adalah 72,00 . Dari 21 orang siswa hanya 9 $(42,85 \%)$ orang siswa yang dapat memenuhi kriteria ketuntasan minimal (KKM). 
Berdasarkan hal tersebut di atas, maka dilakukan identifikasi masalah untuk menemukan cara mengatasi permasalahan tersebut. Hasil identifikasi ditemukan bahwa: (1) hasil belajar siswa rendah; (2) dalam proses pembelajaran siswa hanya mendengarkan penjelasan guru tanpa ada komentar dari siswa bila ada yang belum dimengerti; (3) keberanian siswa untuk bertanya dan mengemukakan pendapat sangat rendah; dan (4) guru belum secara maksimal berfungsi sebagai fasilitator, mediator, dan motivator dalam proses pembelajaran, kurangnya aktivitas siswa dalam pembelajaran mengakibatkan hasil belajar siswa menurun; (5) pembelajaran masih berpusat pada guru . Untuk mengatasi permasalahan di atas, diterapkan model pembelajaran yang relevan yang mampu membangkitkan suasana belajar yang aktif, kreatif, dan menyenangkan. Salah satu model pembelajaran yang diterapkan adalah model pembelajaran yang inovatif sesuai dengan karakteristik siswa.

Salah satu model pembelajaran yang sesuai dengan perubahan paradigma yang semula berpusat pada guru beralih berpusat pada siswa adalah model pembelajaran kooperatif.

Model pembelajaran kooperatif merupakan teknik-teknik kelas praktis yang dapat digunakan guru setiap hari untuk membantu siswa belajar setiap mata pelajaran, mulai dari keterampilan dasar sampai memecahkan masalah yang kompleks (Nur, 2005; Suprijono, 2009; Agustin, dkk, 2013). Dalam pembelajaran kooperatif siswa bekerja bersama dalam 4-6 orang untuk mencapai materi yang diberikan guru. Oleh karena itu pembelajaran kooperatif mengajak peserta didik untuk belajar secara gotong royong dan bekerja sama dalam menyelesaikan suatu masalah, hal ini akan lebih meningkatkan interaksi antar sesama dan membantu peserta didik untuk membina hubungan sosial yang baik dengan rekannya (Ibrahim, 2000; Slavin 2008; Efriza, dkk, 2013).
Salah satu model pembelajaran kooperatif yang sesuai untuk permasalahan yang ada pada penelitian ini adalah pembelajaran kooperatif tipe Student Teams Achievement Divisions (STAD). Model pembelajaran kooperatif tipe Student Teams Achievement Divisions (STAD) dikembangkan untuk meningkatkan hasil belajar siswa. Model ini dipilih karena model pembelajran kooperatif tipe STAD, selain memiliki keunggulan seperti model kooperatif lainnya, terdapat pula keunggulan yang lain yaitu sebagai alternatif terhadap proses pembelajaran siswa hanya mendengarkan penjelasan guru, keberanian siswa untuk bertanya dan mengemukakan pendapat.

Tipe STAD (Student Teams Achievement Divisions) yang merupakan salah satu model pembelajaran kooperatif (Nurhadi, dkk., 2004; Slavin, 2008; Taniredja, 2011) membagi para siswa di dalam kelas menjadi beberapa kelompok atau tim, masing-masing terdiri atas 4 atau 5 anggota kelompok yang anggotanya heterogen, baik jenis kelamin, ras, etnik, maupun kemampuan (rendah, sedang, dan tinggi). Tidak semua tipe dari model pembelajaran kooperatif tersebut bisa dipakai dalam kondisi belajar tetapi harus disesuaikan dengan situasi dan kondisi bila ingin mencapai hasil maksimal.

Penerapan model pembelajaran
kooperatif tipe Student Teams Achievement Divisions (STAD) dalam pembelajaran IPA, pembelajaran diawali dengan pembentukan kelompok yang heterogen untuk demonstrasi fenomena yang bertindak sebagai diskusi. Hal ini bertujuan untuk menggali pengetahuan awal siswa, menanamkan konsep, dan mengembangkan ide-ide baru, serta saling membantu dalam kelompok kecil untuk mempelajari suatu materi.

Pembelajaran kooperatif tipe STAD (Student Teams Achievement Divisions) yang merupakan salah satu model pembelajaran kooperatif yang dikembangkan oleh Robert Slavin (dalam 
Nurhadi, dkk. 2004) membagi para siswa di dalam kelas menjadi beberapa kelompok atau tim, masing-masing terdiri atas 4 atau 5 anggota kelompok yang anggotanya heterogen, baik jenis kelamin, ras, etnik, maupun kemampuan (rendah, sedang, dan tinggi). Hal tersebut dapat mengkondisikan suasana lingkungan yang nyaman bagi siswa dalam proses pembelajaran. Hal ini dikarenakan siswa dapat saling bertukar pendapat dengan teman sebayanya, mendiskusikan masalah, dan siswa yang kurang mampu dalam menyelesaikan suatu masalah dapat belajar dari temannya yang lebih mampu dalam satu kelompok.

Berdasarkan uraian latar belakang diatas maka peneliti akan menetukan judul penelitian. Setelah berdiskusi dengan teman sejawat maka peneliti memilih judul "Penerapan Model Pembelajaran Kooperatif Tipe Student Teams Achievement Divisions (STAD) dapat Meningkatkan Hasil Belajar IPA Siswa Kelas IV SD No 2 Sembung Tahun Pelajaran 2016/2017"

Berdasarkan latar belakang yang telah di uraikan, dapat dirumuskan permasalahan sebagai berikut.

Apakah penerapan

model pembelajaran kooperatif tipe Student Teams Achievement Divisions (STAD) dapat meningkatkan hasil belajar IPA siswa kelas IV SD No 2 Sembung Tahun Pelajaran 2016/2017?

Berdasarkan rumusan masalah tersebut, maka tujuan yang ingin dicapai dalam penelitian adalah untukmengetahui peningkatan hasil belajar IPA setelah penerapanmodel pembelajaran kooperatif tipe Student Teams Achievement Divisions (STAD) pada siswa kelas IV SD No 2 Sembung Tahun Pelajaran 2016/2017.

Pendidikan IPA diharapkan dapat menjadi wahana bagi peserta didik untuk mempelajari diri sendiri dan alam sekitar, serta prospek pengembangan lebih lanjut dalam menerapkannya di dalam kehidupan sehari-hari. Sebagaimana yang dikemukakan Darmojo (1993), "IPA adalah pengetahuan rasional dan objektif tentang alam semesta dengan segala isinya". Rasional artinya masuk akal atau logis, diterima oleh akal sehat, sedangkan objektif artinya sesuai dengan objeknya, sesuai dengan kenyataannya, atau sesuai dengan pengalaman pengamatan melaui panca indra. Nash (dalam Darmojo, 1993), mengatakan bahwa "science is a way of looking at the world", yang artinya IPA itu suatu cara atau metode untuk mengamati alam.

Berdasarkan pada pengertian IPA tersebut, maka dapat disintesiskan bahwa hakikat IPA di SD merupakan pengetahuan rasional dan objektif yang meliputi tiga bidang ilmu dasar, yaitu biologi, fisika, dan kimia dimana mempelajari tentang alam semesta dengan segala isinya dalam kehidupan sehari-hari. Pendidikan IPA diharapkan dapat menjadi wahana bagi peserta didik untuk mempelajari diri sendiri dan alam sekitar, serta prospek pengembangan lebih lanjut dalam menerapkannya di dalam kehidupan sehari-hari. IPA bukan hanya pengusaan kumpulan pengetahuan yang berupa fakta-fakta,konsep-konsep atau prinsip saja tetapi juga merupakan suatu proses penemuan. Oleh sebab itu guru dituntut untuk merancang proses pembelajaran yang melibatkan siswa didalamnya.

Pendidikan IPA menekankan pada pemberian pengalaman langsung dan kegiatan praktis untuk mengembangkan kompetensi agar siswa mampu menjelajahi dan memahami alam sekitar secara ilmiah. Dalam Permendiknas No. 22 Tahun 2006 menjelaskan bahwa mata pelajaran IPA SD/MI bertujuan agar peserta didik memiliki kemampuan sebagai berikut. a) memperoleh keyakinan terhadap kebesaran Tuhan Yang Maha Esa berdasarkan keberadaan, keindahan, dan keteraturan alam ciptaan-Nya. b) mengembangkan pengetahuan dan pemahaman konsep-konsep IPA yang bermanfaat dan dapat diterapkan dalam kehidupan sehari-hari. c) mengembangkan 
rasa ingin tahu, sikap positif dan kesadaran tentang adanya hubungan yang saling mempengaruhi antara IPA, lingkungan, teknologi, dan masyarakat. d) mengembangkan keterampilan proses untuk menyelidiki alam sekitar, memecahkan masalah, dan membuat keputusan. e) meningkatkan kesadaran untuk berperanserta dalam memelihara, menjaga, dan melestarikan lingkungan alam. f) meningkatkan kesadaran untuk menghargai alam dan segala keteraturannya sebagai salah satu ciptaan Tuhan. g) memperoleh bekal pengetahuan, konsep, dan keterampilan IPA sebagai dasar untuk melanjutkan pendidikan ke SMP/MTs.

Sesuai dengan Peraturan Menteri Pendidikan Nasional RI No 22 Tahun 2006 Tentang Standar Kompetensi dan Kompetensi Dasar, ruang lingkup bahan kajian IPA untuk SD/MI meliputi aspekaspek (1) makhluk hidup dan proses kehidupan; (2) benda atau materi, sifat, dan kegunaanya; (3) energi dan perubahannya; dan (4) bumi dan alam semesta.

Hasil belajar adalah hasil yang diperoleh siswa setelah mengalami interaksi proses pembelajaran (Agung, 2005). Menurut Sudjana (2010) menyatakan hasil belajar adalah kemampuan-kemampuan yang dimiliki siswa setelah ia menerima pengalaman belajar. Degeng (dalam Wena, 2009) menyatakan hasil belajar adalah semua efek yang dapat dijadikan indikator tentang nilai penggunaan strategi pembelajaran di bawah kondisi yang berbeda.

Hasil belajar menunjukkan keberhasilan siswa dalam mata pelajaran tertentu. Hasil belajar IPA adalah kemampuan yang diperoleh siswa setelah mengikuti proses pembelajaran IPA. Hasil belajar yang mencerminkan penguasaan kompetensi yang semestinya dimiliki oleh peserta didik.

Sumadi Suryabrata (1995) yang menyatakan bahwa faktor-faktor yang mempengaruhi hasil belajar dapat digolongkan menjadi dua yaitu faktor internal dan faktor ekstrelnal. Model ini dikembangkan oleh Robert Slavin dan teman-temannya di Universitas John Hopkin.

Menurut Slavin (20) model STAD (Student Team Achievement Divisions) merupakan variasi pembelajaran kooperatif yang paling banyak diteliti. Dalam STAD, siswa dibagi menjadi kelompok beranggotakan empat orang yang beragam kemampuan, jenis kelamin, dan sukunya. Guru memberikan suatu pembelajaran dan siswa-siswa didalam kelompok memastikan bahwa semua anggota kelompok bisa menguasai pelajaran tersebut. Akhirnya semua siswa menjalani kuis perseorangan tentang materi tersebut, dan pada saat itu mereka tidak boleh saling membantu satu sama lain. Nila-nilai hasil kuis mereka diperbandingkan dengan nilai rata-rata mereka sendiri yang diperoleh sebelumnya dan nilai-nilai itu diberi hadiah berdasarkan seberapa tinggi peninggkatan yang mereka capai atau seberapa tinggi nilai itu melampaui nilai mereka sebelumnya. Nilainilai ini kemudian dijumlahkan untuk mendapatkan nilai kelompok, dan kelompok yang dapat mencapai kriteria tertentu bisa mendapatkan sertifikat. Keseluruhan aktivitas siklus itu, mulai dari paparan guru ke kerja kelompok sampai kuis, biasanya memerlukan tiga sampai lima kali pertemuan kelas.

Slavin (dalam Marhaeni, 2006), model pembelajaran kooperatif tipe $S T A D$ terdiri dari lima komponen utama yang harus diperhatikan yaitu: tahap penyajian kelas (class presentation), belajar dalam kelompok (teams). Tes/kuis (quizzes), skor kemajuan individu (individual improvement scores), dan penghargaan kelompok (team recognition).

\section{METODE}

Penelitian ini merupakan penelitian tindakan kelas (PTK) yang secara umum bertujuan meningkatkan dan memperbaiki 
kualitas proses pembelajaran di kelas yang bermuara pada peningkatan hasil belajar IPA siswa. Penelitian ini dilaksanakan pada satu kelas yang mempunyai masalah pembelajaran.

Pelaksanaan tindakan kelas pada penelitian ini dilaksanakan bersiklus dan tiap-tiap siklus terdiri dari empat tahapan yaitu: (a) perencanaan; (b) pelaksanaan; (c) observasi/evaluasi; dan (d) refleksi. Siklus I dan siklus-siklus berikutnya dilaksanakan untuk mengkaji variabel yang diteliti yaitu hasil belajar. Siklus-siklus tersebut dapat digambarkan dalam model seperti gambar berikut:
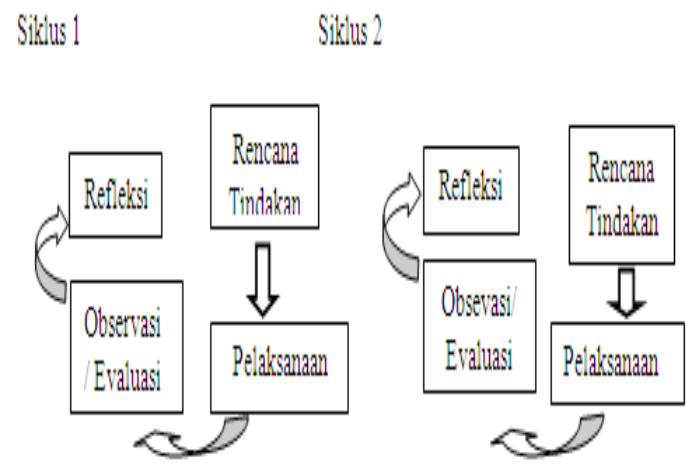

Gambar : 1. Rancangan Penelitian Tindakan Kelas (Kasihani, 2007)

Subjek penelitian tindakan kelas ini adalah siswa kelas IV SD No 2 Sembung Tahun Pelajaran 2016/2017 dengan mata pelajaran IPA. Jumlah siswa sebanyak 21 orang. Dengan laki-laki sebanyak 9 orang dan perempuan 12 orang. Objek penelitian tindakan ini adalah model pembelajaran Student Teams Achievement Division (STAD) hasil belajar IPA siswa.

\section{HASIL DAN PEMBAHASAN}

Berdasarkan permasalahan yang dipaparkan pada bagian pendahuluan, maka diadakan PTK dengan menerapkan model pembelajaran Kooperatif Tipe Student Teams Achievement Division (STAD) pada mata pelajaran IPA siswa kelas IV di SD No 2 Sembung Tahun Pelajaran 2016/2017. Penelitian ini dilaksanakan dengan kolaborasi bersama guru mata pelajaran IPA baik pada perencanaan maupun proses pembelajaran di kelas.

Data yang dikumpulkan pada penelitian ini yaitu data mengenai hasil belajar siswa dengan penerapan model pembelajaran Kooperatif Tipe Student Teams Achievement Division (STAD). Penelitian ini dilaksanakan dalam 2 siklus, dimana setiap siklus dilaksanakan dalam 3 kali pertemuan yaitu 2 kali pertemuan untuk pembelajaran dan 1 kali pertemuan untuk tes.Selanjutnya, data yang didapatkan melalui penerapan model Kooperatif Tipe Student Teams Achievement Division (STAD) ini dianalisis berdasarkan metode analisis data yang telah dijelaskan pada bab III. Adapun hasil analisis data mengenai aktivitas dan hasil belajar siswa dapat dipaparkan sebagai berikut.

Berdasarkan refleksi awal mengenai hasil belajar siswa yang rendah, maka kegiatan pada tahap pertama sesuai langkah penelitian tindakan yang dimulai dengan perencanaan, pelaksanaan, observasi/evaluasi dan refleksi. Pada tahap perencanaan ini kegiatan yang dilakukan adalah (1) berkoordinasi dengan kepala sekolah untuk melaksanakan penelitian; (2) mensosialisasikan model pembelajaran Student Teams Achievement Division (STAD) kepada guru mitra; (3) berkolaborasi dengan guru menyusun Rencana Pelaksanaan Pembelajaran (RPP) dilengkapi LKS dengan langkah-langkah pembelajaran yang sesuai dengan model pembelajaran Student Teams Achievement Divisions (STAD); (4) menyiapkan alat dan bahan yang akan digunakan dalam kegiatan pembelajaran; dan (5) menyiapkan instrumen lembar observasi.

Siklus I dilaksanakan dalam tiga kali pertemuan, yaitu pertemuan pertama dan kedua untuk pelaksanaan tindakan pada tanggal 20 Oktober dan 26 Oktober 2016 selanjutnya pertemuan ketiga untuk mengadakan tes akhir siklus I dilaksanakan pada tanggal 27 Okober 
2016. Secara garis besar kegiatan pembelajaran di setiap pertemuan dibagi menjadi tiga yaitu: 1) kegiatan awal; 2) kegiatan inti; dan 3) kegiatan akhir.

Observasi dilaksanakan pada saat dilaksanakannya pembelajaran pada siklus I pertemuan pertama dan kedua. Observasi ini dilakukan oleh guru sebagai observer. Observer melakukan pengamatan terhadap aktivitas belajar siswa yang mengacu pada lembar obsevasi yang telah dirancang sesuai dengan model pembelajaran Student Teams Achievement Divisions (STAD).

Evaluasi mengenai hasil belajar IPA siswa pada siklus I dinilai dengan menggunakan tes hasil belajar yang terdiri dari tes pilihan ganda berjumlah 20 soal.

Tabel 1 data hasil belajar IPA siswa kelas IV SD No 2 Sembung pada siklus I

\begin{tabular}{cccc}
\hline NO & KODE SISWA & NILAI & KETERANGAN \\
\hline 1 & $\mathrm{~A}$ & 56 & Tidak Tuntas \\
2 & $\mathrm{~B}$ & 73 & Tuntas \\
3 & $\mathrm{C}$ & 75 & Tuntas \\
4 & $\mathrm{D}$ & 56 & Tidak Tuntas \\
5 & $\mathrm{E}$ & 77 & Tuntas \\
6 & $\mathrm{~F}$ & 75 & Tuntas \\
7 & $\mathrm{G}$ & 54 & Tidak Tuntas \\
8 & $\mathrm{H}$ & 46 & Tidak Tuntas \\
9 & $\mathrm{I}$ & 47 & Tidak Tuntas \\
10 & $\mathrm{~J}$ & 82 & Tuntas \\
11 & $\mathrm{~K}$ & 71 & Tuntas \\
12 & $\mathrm{~L}$ & 74 & Tuntas \\
13 & $\mathrm{M}$ & 75 & Tuntas \\
14 & $\mathrm{~N}$ & 69 & Tidak Tuntas \\
15 & $\mathrm{O}$ & 79 & Tuntas \\
16 & $\mathrm{P}$ & 77 & Tuntas \\
17 & $\mathrm{Q}$ & 59 & Tidak Tuntas \\
18 & $\mathrm{R}$ & 77 & Tuntas \\
19 & $\mathrm{~S}$ & 75 & Tuntas \\
20 & $\mathrm{~T}$ & 55 & Tidak Tuntas \\
21 & $\mathrm{U}$ & 78 & Tuntas \\
\hline \multicolumn{5}{c}{ Jumlah } & 1430 & \\
\hline Rata-Rata & 68,08 & Sedang \\
\hline Ketuntasan & $68,08 \%$ & Rendah \\
\hline
\end{tabular}

Berdasarkan hasil implementasi Rencana Pelaksanaan Pembelajaran (RPP) dengan menggunakan model pembelajaranStudent Teams Achievement Divisions (STAD) pada siklus I, ternyata masih terdapat banyak kekurangan terutama pada aktivitas dan hasil belajar yang diperoleh siswa. Maka dari itu dilanjutkan pada pertemuan siklus II. Upaya perbaikan yang dilakukan pada siklus II untuk meningkatkan pencapaian Standar Kompetensi (SK) dan
Kompetensi Dasar (KD), serta penjabaran indikator yang harus dicapai oleh siswa dapat tercapai secara optimal, guru mempersiapkan hal-hal yang pada dasarnya sama dengan siklus I, namun perencanaan tindakan pada siklus II disesuaikan dengan hasil refleksi pada siklus I. Perbaikan yang dilaksanakan untuk mengatasi masalah pada siklus I yaitu: 1) menumbuhkan rasa ingin tahu siswa, supaya mereka merasa senang dan bersemangat dalam mengikuti 
pembelajaran di kelas; 2) menjelaskan tujuan dan kegiatan pembelajaran yang akan dilakukan; 3) melakukan pendekatan secara individu terutama pada siswa yang hasil belajarnya kurang; dan 4) memberikan penghargaan kepada siswa yang mengajukan pertanyaan atau pada siswa yang menanggapi hasil pekerjaan yang disampaikan oleh kelompok penyaji.

Pelaksanaan tindakan siklus II disesuaikan dengan kegiatan refleksi siklus I yang bertujuan untuk mengantisipasi kekurangan-kekurangan dalam proses pembelajaran agar hasilnya maksimal sehingga diharapkan penelitian ini dapat dikatakan berhasil. Siklus II ini dilaksanakan sama seperti siklus I yaitu dalam tiga kali pertemuan. Masing-masing pertemuan berlangsung selama 2 jam pelajaran (2x 35 menit). Siklus II dilaksanakan tiga kali pertemuan, yaitu pertemuan pertama dan kedua untuk pelaksanaan tindakan pada tanggal 2 dan 3 Nopember 2016, selanjutnya pertemuan ketiga untuk mengadakan tes akhir siklus II dilaksanakan pada tanggal 9 Nopember 2016. Secara garis besar kegiatan pembelajaran di setiap pertemuan dibagi menjadi tiga yaitu: 1) kegiatan awal; 2) kegiatan inti; dan 3) kegiatan akhir.

Observasi dilaksanakan pada saat dilaksanakannya pembelajaran pada siklus II pertemuan pertama dan kedua. Observasi ini dilakukan oleh guru sebagai observer. Observer melakukan pengamatan terhadap aktivitas belajar siswa yang mengacu pada lembar observasi yang telah dirancang sesuai dengan model pembelajaran STAD.

Tabel 1 data hasil belajar IPA siswa kelas IV SD No 2 Sembung pada siklus II

\begin{tabular}{|c|c|c|c|}
\hline No & Kode siswa & Nilai & Keterangan \\
\hline 1 & A & 71 & Tidak Tuntas \\
\hline 2 & B & 78 & Tuntas \\
\hline 3 & C & 78 & Tuntas \\
\hline 4 & D & 80 & Tuntas \\
\hline 5 & $\mathrm{E}$ & 80 & Tuntas \\
\hline 6 & $\mathrm{~F}$ & 80 & Tuntas \\
\hline 7 & G & 71 & Tidak Tuntas \\
\hline 8 & $\mathrm{H}$ & 80 & Tuntas \\
\hline 9 & I & 78 & Tuntas \\
\hline 10 & $\mathrm{~J}$ & 98 & Tuntas \\
\hline 11 & $\mathrm{~K}$ & 78 & Tuntas \\
\hline 12 & $\mathrm{~L}$ & 83 & Tuntas \\
\hline 13 & M & 80 & Tuntas \\
\hline 14 & $\mathrm{~N}$ & 90 & Tuntas \\
\hline 15 & 0 & 80 & Tuntas \\
\hline 16 & $\mathrm{P}$ & 80 & Tuntas \\
\hline 17 & Q & 80 & Tuntas \\
\hline 18 & $\mathrm{R}$ & 83 & Tuntas \\
\hline 19 & S & 80 & Tuntas \\
\hline 20 & $\mathrm{~T}$ & 80 & Tuntas \\
\hline 21 & $\mathrm{U}$ & 83 & Tuntas \\
\hline \multicolumn{2}{|c|}{ Jumlah } & 1692 & \\
\hline \multicolumn{2}{|c|}{ Rata-Rata } & 80,57 & \\
\hline \multicolumn{2}{|c|}{ Rata-Rata Presentase } & $80,77 \%$ & Tinggi \\
\hline \multicolumn{2}{|c|}{ Ketuntasan Be Lajar } & $90,47 \%$ & Sangat Tinggi \\
\hline
\end{tabular}


Berdasarkan tabel hasil belajar, maka dapat diketahui bahwa rata-rata hasil belajar siswa pada siklus II sebesar 80,57. Rata-rata persentase hasil belajar siswa sebesar $80,57 \%$ yang berada pada kategori tinggi, dan diketahui bahwa ada dua orang siswa yang belum tuntas sesuai $\mathrm{KKM} \geq 72$, sehingga diperoleh ketuntasan belajar siswa secara klasikal sebesar $90,47 \%$ yang berada pada kategori sangat tinggi. Berdasarkan PAP skala lima, berarti rata-rata persentase hasil belajar dan ketuntasan belajar (KB) siswa secara klasikal sudah memenuhi target minimal yang telah ditentukan yaitu $75 \%$.

Berdasarkan analisis data hasil belajar pada siklus I dan siklus II dapat dijelaskan bahwa hasil penelitian tentang hasil belajar IPA diperoleh angka persentase rata-rata klasikal pada siklus I adalah $68,09 \%$ dan pada siklus II adalah $80,57 \%$. Ketuntasan belajar pada siklus I adalah $57,14 \%$ dan pada siklus II adalah $90,47 \%$, sehingga dalam penelitian ini ketuntasan belajar siswa sudah melebihi target yang telah ditetapkan yaitu pada kategori sangat tinggi.

\section{PEMBAHASAN}

Berdasarkan hasil penelitian yang telah dilaksanakan dalam siklus I hasil belajar IPA yang diperoleh juga belum mencapai kriteria ketuntasan yang ditetapkan. Persentase rata-rata klasikal hasil belajar IPA sebesar 68,09\% dengan kategori sedang. Ketuntasan belajar pada siklus I sebesar $57,14 \%$, hal ini belum mencapai kriteria ketuntasan yang ditetapkan.

Setelah penyempurnaan pada siklus II, maka diperoleh peningkatan hasil belajar IPA. Persentase rata-rata klasikal hasil belajar IPA diperoleh persentase rata-rata klasikal sebesar $80,57 \%$ dengan kategori tinggi. Ketuntasan belajar pada siklus II sebesar 90,47\%, hal ini sudah mencapai kriteria ketuntasan yang ditetapkan. Dengan demikian, dari siklus I ke siklus II hasil belajar mengalami peningkatan sebanyak 12,48\%. Ketuntasan belajar dari siklus I ke siklus II mengalami peningkatkan sebanyak $33,33 \%$.

Dari pembahasan di atas, secara umum telah mampu menjawab rumusan masalah. Penelitian ini dapat dikatakan berhasil, karena semua kriteria yang ditetapkan telah terpenuhi. Jadi, dapat disimpulkan bahwa penerapan model pembelajaran kooperatif tipe Student Teams Achievement Divisions (STAD) dapat meningkatkan hasil belajar IPA siswa kelas IV SD No. 2 Sembung tahun pelajaran 20016/2017.

\section{SIMPULAN DAN SARAN}

Berdasarkan hasil penelitian dan pembahasan seperti disajikan dalam bab IV, maka penerapan model pembelajaran kooperatiftipe STAD telah berhasil meningkatkan hasil belajar IPA siswa kelas IV semester ganjil di SD No. 2 Sembung tahun pelajaran 2016/2017. Hal ini dapat dilihat pada siklus I diperoleh rata-rata persentase hasil belajar sebesar $68,09 \%$ berada pada kategori sedang dan pada siklus II rata-rata persentasehasil belajar meningkat menjadi $80,57 \%$ berada pada kategori tinggi. Sedangkan ketuntasan belajar pada siklus I sebesar $57,14 \%$ dan meningkat pada siklus II menjadi 90,47\%. Dengan demikian, persentase hasil belajar dari siklus I satu ke siklus II mengalami peningkatan sebesar $12,48 \%$, dan ketuntasan belajar dari siklus I ke siklus II mengalami peningkatan sebesar 33,33\%.

Berdasarkan hasil penelitian tindakan ini, disampaikan beberapa saran sebagai berikut. 1. kepada siswa disarankan untuk menguasai dan memahami konsep belajar IPA. Dengan belajar IPA siswa dapat memperoleh pengalaman belajar bermakna yang dapat digunakan dalam kehidupan sehari-hari. 2 . kepada guru sekolah dasar agar dalam 
mengajar IPA menggunakan model pembelajaran yang inovatif, salah satunya model pembelajaran STAD yang dapat menunjang hasil belajar siswa, sehingga tidak ada lagi strategi mengajar berpusat pada guru yang menyebabkan siswa kurang aktif belajar. 3. kepada pembaca yang berminat untuk mengadakan penelitian lebih lanjut mengenai model pembelajaran kooperatif tipe STAD pada bidang ilmu IPA maupun pada bidang ilmu lainnya yang sesuai, agar memperhatikan kendala-kendala yang peneliti alami sebagai bahan pertimbangan untuk dapat membuat rancangan yang lebih sempurna.

\section{DAFTAR PUSTAKA}

Agung, A.A. Gede. 2005. Metodelogi Penelitian Pendidikan. Singaraja: Fakultas IImu Pendidikan, IKIP Negeri Singaraja.

Agustin, Setya \& Aryanto, Sugeng. Antara, Sukma. 2013. The Effect Of Using Numbered Head Together Technique On The Eighth Grade Students' Reading Comprehension Achievement At Smpn 2 Tanggul Jember Jurnal Pancaran. 2 (3). 201-210.

Darmojo, Hendro., Jenny R.E Kaligis. 1993. Pendidikan IPA 2. Jakarta: Depdikbud

Dimyati \& Mudjono. 1994. Belajar dan Pembelajaran. Jakarta: Proyek Pembinaan dan Peningkatan Mutu Tenaga Kependidikan. Direktorat Jendral Pendidikan Tinggi Departemen Pendidikan dan Kebudayaan.

Efriza, Dony \& Mukhaiyar, Radja. D. 2013. The Effect Of Using Numbered Heads Together And Reading Motivation On Students' Reading Comprehension Of Descriptive And Narrative Text Of Smpn 7 Muaro Jambi. Journal English Language Teaching (ELT). 1 (3). 65-74.
Hariyanto. (2011,17 Desember). Pengertian Model Pembelajaran. Diperoleh 7 Oktober 2016, dari http://belajarpsikologi.com/pengerti an-model-pembelajaran.

Ibrahim, M, dkk. 2000. Pembelajaran Kooperatif. Surabaya: University Press

Kasihani Kasbullah. (1999). Penelitian Tindakan Kelas. Jakarta: Depdikbud.

Marhaeni, A.A.I.N. 2006. Assesment Portofolio Dalam Pembelajaran Berbasis Kompetensi. Bali: Universitas Pendidikan Ganesha Singaraja.

Nur, Mohamad. 2005 Depdiknas.. Pembelajaran Kooperatif. Jawa Timur:

Nurhadi, dkk. 2004. Pembelajaran Kontekstual dan Penerapannya dalam KBK. Surabaya: Universitas Negeri Malang.

Permendiknas No. 22 Tahun 2006 tentang Standar Isi untuk Satuan Pendidikan Dasar dan Menengah. 2006. Jakarata: Departemen Pendidikan Nasional.

Rusman. $2011 . \quad$ Model-model Pembelajaran Mengembangkan Profesionalime Guru. Jakarta : PT Rajagrafindo Persada.

Slavin, Robert. E. 2008. Cooperative Learning (Teori, Riset dan Praktek). Bandung: Nusa Media

Slavin, Robert. E 2010. Cooperative Learning Teori, Riset dan Praktik. Bandung:Nusa Media

Sudjana, Nana. 2010. Penilaian Hasil Proses Belajar Mengajar. Bandung: PT Remaja Rosdakarya.

Suprijono, Agus. 2009. Cooperative Learning Teori \& Aplikasi Paikem. Surabaya: Pustaka Pelajar. 
Suryabrata, Sumadi. 1995. Psikologi Pendidikan. Bandung: Angkasa.

Taniredja, Tukirman, dkk. 2012. ModelModel Pembelajaran Inovatif . Bandung:Alfabeta

Trianto. 2012. Model Pembelajaran Terpadu. Jakarta : Bumi Aksara
Undang-Undang Republik Indonesia Nomor 20 Tahun 2003 tentang Sistem Pendidikan Nasional. 2003. Jakarta: Departemen Pendidikan Nasional.

Wena, Made. 2009. Strategi Pembelajaran Inovatif Kontemporer: Suatu Tinjauan Konseptual Operasional. Jakarta: PT. Bumi Aksara. 